Original Research Paper

\title{
Optimal Planning and Design of an Environmentally Friendly Hybrid Energy System for Rural Electrification in Iraq
}

\author{
Ali Saleh Aziz and Sara Ahmed Khudhier \\ Department of Medical Instrumentation Engineering Techniques, Al-Hussain University College, Karbala, Iraq
}

\author{
Article history \\ Received: 21-10-2016 \\ Revised: 06-01-2017 \\ Accepted: 25-01-2017 \\ Corresponding Author: \\ Ali Saleh Aziz \\ Department of Medical \\ Instrumentation Engineering \\ Techniques, Al-Hussain \\ University College, Karbala, \\ Iraq \\ Email:iraq_1991@yahoo.com
}

\begin{abstract}
Current power systems create environmental effects because of the using of fossil fuels, specially coal, since $\mathrm{CO}_{2}$ is released to the atmosphere. Contrary to conventional energy sources, renewable energy sources produce a clean energy which is in general free of pollution, environmentally sustainable and technologically efficient. There is an increased interest in solar energy that can generate electricity with no greenhouse gas emissions. Photovoltaic systems are used to convert the sunlight into electricity. The goal of this research is to design an optimum off-grid photovoltaic/diesel hybrid energy system for a remote hamlet in Al-Kuwayr region north of Iraq. HOMER software is used to implement the techno-economic and environmental feasibility study of the proposed system. It simulates all feasible system which fulfill the load of the chosen sites under specific conditions of the available renewable resources. The analysis of the optimum hybrid energy system is presented to estimate the standalone electrification and compare it with grid expansion. The simulation results show that the optimum hybrid power system consists of $25 \& 50 \mathrm{~kW}$ diesel generators, $60 \mathrm{~kW}$ photovoltaic arrays and $40 \mathrm{~kW}$ converter with no batteries. The power system is capable of providing up to $64 \mathrm{~kW}$ peak load. Furthermore, the off-grid photovoltaic/diesel system is found to be more frugal than grid expansion.
\end{abstract}

Keywords: Emissions, Solar Energy, Diesel, Hybrid, Total Net Present Cost (NPC)

\section{Introduction}

A current issue of public focus is the requirement for potent, sustainable and environment friendly energy systems that are smart, effective and clean. Existing energy systems have a negative climate effects because of the using of fossil fuels, as different types of emissions are emitted into the atmosphere. Alternative energy sources are being used as a solution for the global warming issues (Shafiullah et al., 2010).

In Arabian Peninsula countries, solar energy has not yet been fully exploited because of the abundant and cheap supply of oil. Currently, governments have no incentive to consider renewable energy and saving the climate is not a high priority in the region. Iraqi governments and people are not completely aware of the significance of renewable energy and therefore, the growth of such technology within the region is primarily the result of individual initiatives and nongovernmental organizations.
In spite of the abundant of fossil fuels in Iraq, energy shortages started in 1991 because of the disruption caused by the comprehensive destruction of the country (Al-Douri and Abed, 2015).

The most important type of renewable energy available in Iraq is the solar energy. Throughout the year, the area enjoys a massive amount of solar radiation throughout the twelve months of the year (Kazem et al., 2014).

Until the present, most of the remote rural regions in Iraq are rudimentary and in a messy situation as a result of the infestation and there is a necessity to supply these regions with electricity. Because of their remote location from the central grid, most of these areas use diesel generators for their electricity. Beside their harmful emission, the seepage of diesel from generators is found to pollute the natural underground water resources. In this view, the only alternative of fossil fuels is the use of new energy resources in a clean and silent mode. Standalone Photovoltaic (PV) or hybrid PV/diesel can play a major role in the 
growth of the regions through minimizing the using of fossil fuels (Al-Karaghouli and Kazmerski, 2010).

In order to investigate the optimum design of hybrid energy systems for the remote areas, many studies have been performed in this field. Al-Karaghouli and Kazmerski (2010) discussed the need for supplying the electricity for remote areas located south of Iraq and proposed a photovoltaic system to supply electricity for a health clinic in that area. They concluded that utilizing the photovoltaic system is justified on economic, technical and social bases.

Kaldellis (2010) improved a methodology to investigate the optimal size of a hybrid energy system, whilst reducing the total cost of the system. They concluded that the proposed energy system consisting of diesel, photovoltaic, batteries and inverter is the best feasible system to supply the telecommunication stations with electricity.

The optimum design of a hybrid energy system consisting of wind turbine, photovoltaic and batteries was discussed by Nandi and Ghosh (2009). The results indicated that wind-PV-battery is the best optimum feasible hybrid energy system.

In this study, techno-economic study of dieselphotovoltaic hybrid energy system to provide electricity for remote rural area in Iraq is discussed and compared with the grid extension system.

\section{Materials and Methods}

\section{HOMER Software}

In this study, a simulation model was produced in HOMER for designing and evaluating the feasible hybrid energy systems in order to electrify the selected village. It simulates and optimizes an electric power system combining nonrenewable and renewable energy sources for both on-grid and off-grid. In this software, the inputs data includes loads, renewable components data like wind turbine and PV specifications, kinds of converters and batteries, capital, costs of the components and fuels cost and renewable resources data such as wind speeds and solar radiations.

HOMER simulates thousands of combinations and selects the most feasible systems which are sorted by total Net Present Cost (NPC) (Nour and Rohani, 2014).

\section{Description of the Selected Village}

The selected location is one of remote hamlet in AlKuwayr area north of Iraq. It is populated by about 280 people. Currently, load demands are supplied by operating 50 and $25 \mathrm{~kW}$ diesel generators. The location of this village in Iraq is shown in Fig. 1.

\section{Load Profiles of the Village and Electrification}

During the summer season (June-October), the daily load demand in the village is shown in Fig. 2. Through the winter season (November-February), the load of each hour would be reduced by $2 \mathrm{~kW}$. During March to May, the load would be reduced to $3 \mathrm{~kW}$ for each hour. A random variability of 5\% is applied for both day-to- day and time-step-to-time-step so as to assessment the variations which may be happened every day. Figure 3 shows the seasonal load profile.

Moreover, deferrable load of $30 \mathrm{kWh} /$ day is applied in this study. Water pumping and ice making are some of the activities performed by the deferrable load.

\section{Solar Radiation Resource}

The monthly average daily radiation is shown in Fig. 4. It represents the monthly clearness index of AlKuwayr. All the data was collected for latitude 34" 9' North and longitude 42" 26 ' East. It can be observed that the solar radiation reaches its highest level during the summer season with a daily radiation of $7.6 \mathrm{kWh} / \mathrm{m}^{2} / \mathrm{d}$ in June. During the winter season it attains its lowest level with a daily radiation of $2.6 \mathrm{kWh} / \mathrm{m}^{2} / \mathrm{d}$ in December (Nawawi et al., 2016).

\section{System Components}

\section{System Description}

The energy produced by the photovoltaic and the batteries has primacy to feed the load. The backup diesel generator is turned on whenever the battery is discharged to its lowest acceptable value and the energy produced by PV system to supply the load and charge the batteries is not enough. HOMER compares the load demands and the available energy supplied by the PV system for each hour step. Charge and discharge the batteries or run the diesel generator will be decided based on this comparison. When the generated energy surpasses the load demands and the battery are totally charged, the surplus energy is consumed by a deferrable load. Figure 5 shows the configuration of a diesel-photovoltaic hybrid power generation system. Figure 6 presents the designed hybrid system in HOMER software.

\section{PV System}

Photovoltaic's panels are the main electrical source of the proposed system which converts solar irradiation directly into Electricity. The details of technical parameters and costs of PV module are provided in Table 1 (Sunderland et al., 2013).

\section{Battery}

In order to store the energy, lead acid batteries are used in this simulation for economical consideration. The utilize of hydrogen as another potential storage system is not presently economically because of the high costs of its components such as the electrolyzers and fuel cells and the low efficiency resulting from the conversion cycle (electricity-hydrogen-electricity). 


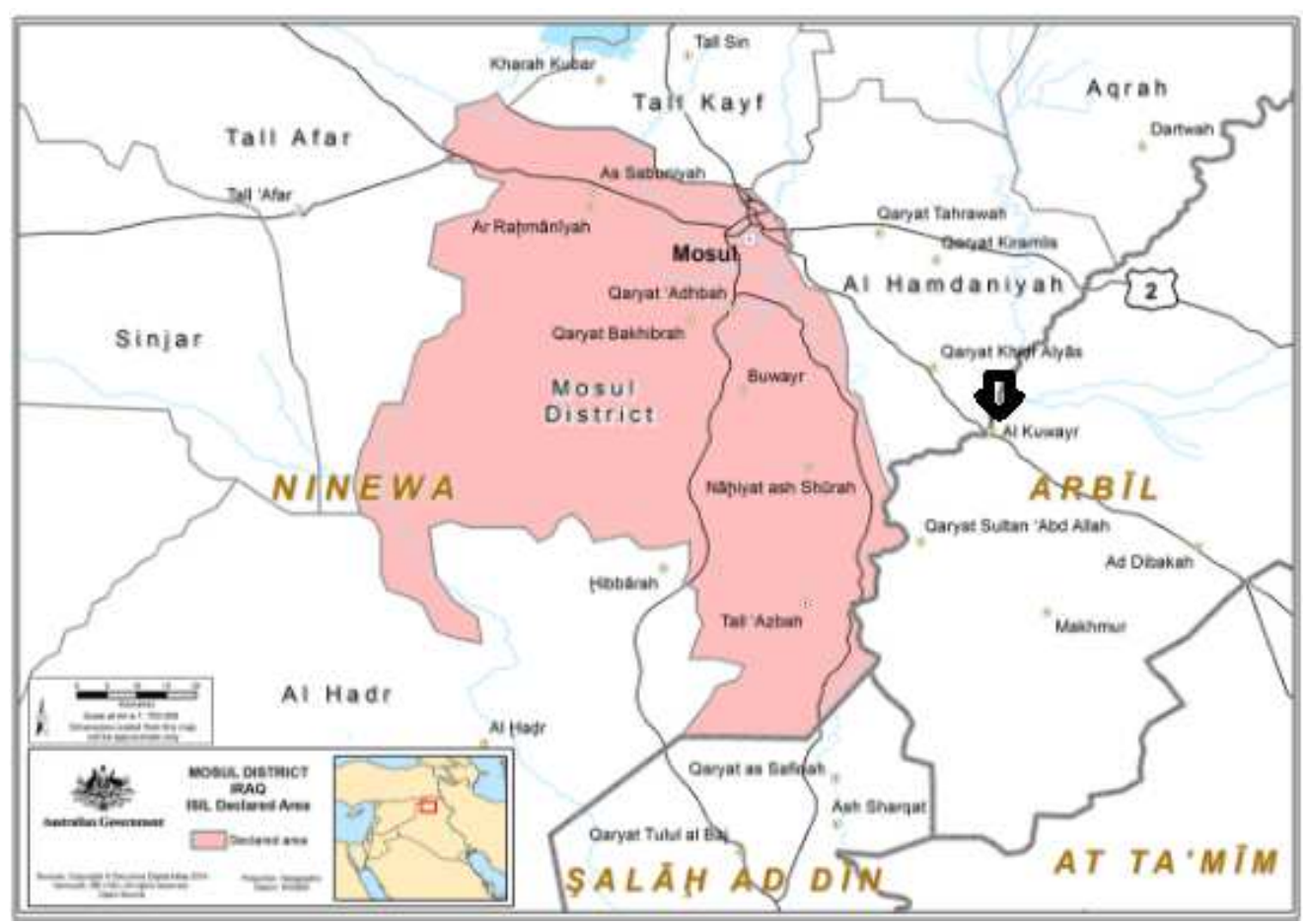

Fig. 1. Location of the selected village

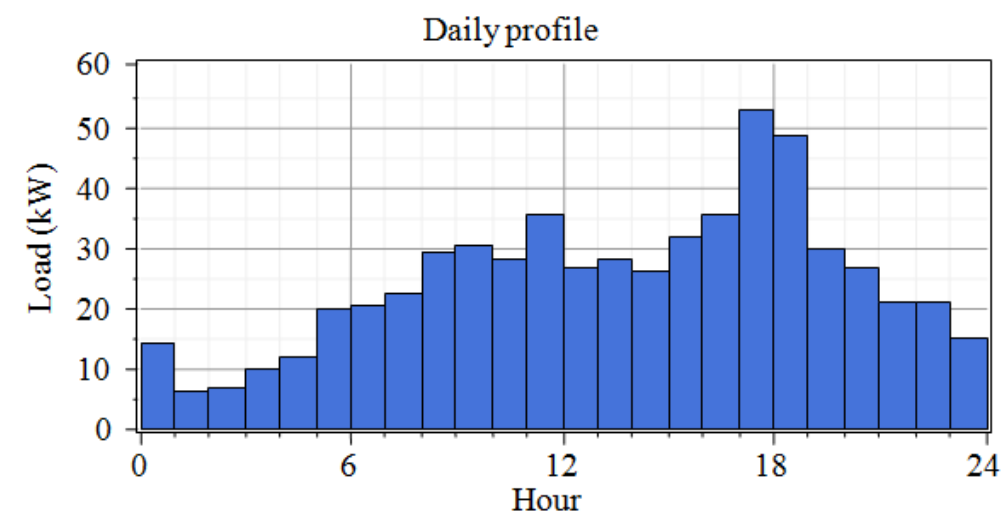

Fig. 2. The daily load demand in the village during June to October

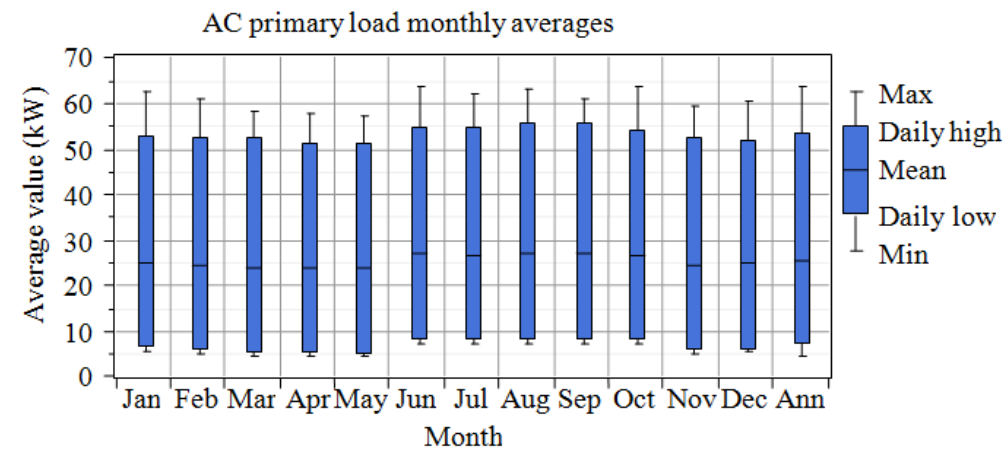

Fig. 3. Monthly averages load profile (Nawawi et al., 2016) 


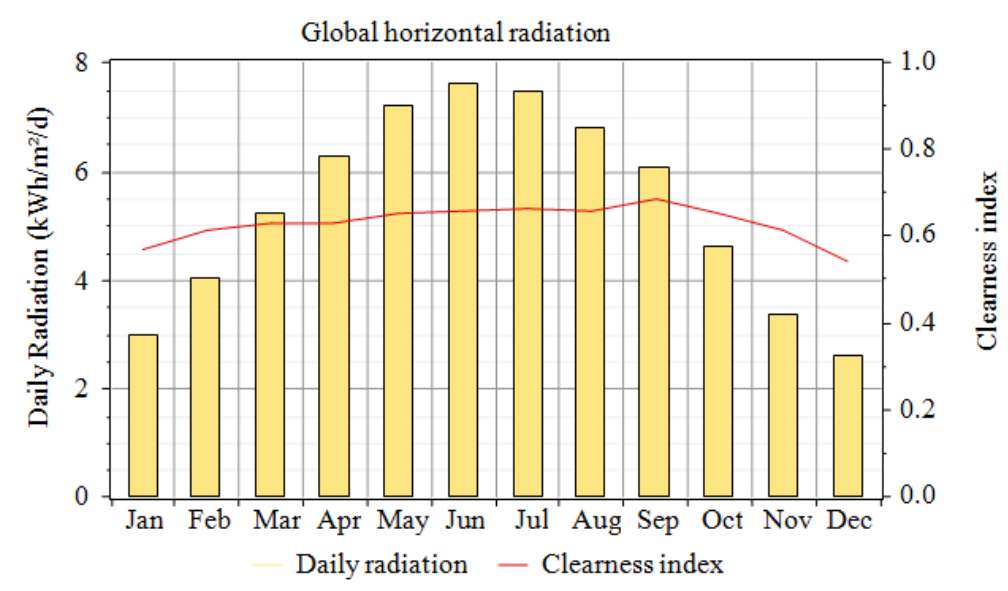

Fig. 4. Monthly average daily radiation and clearness index

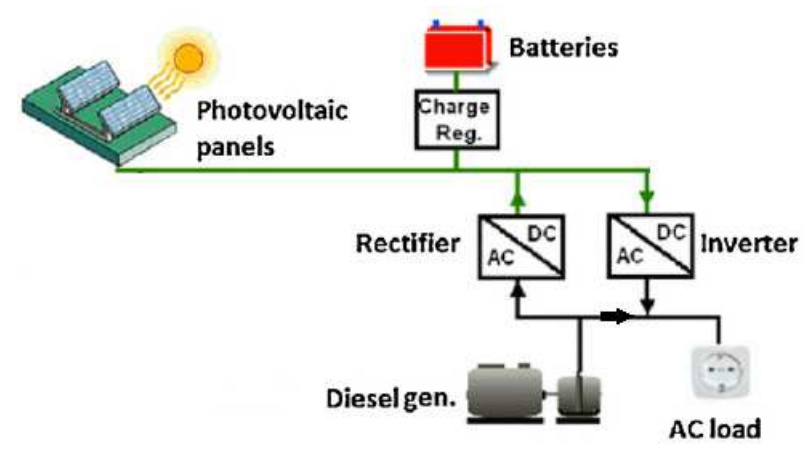

Fig. 5. The configuration of a PV/diesel hybrid power generation system

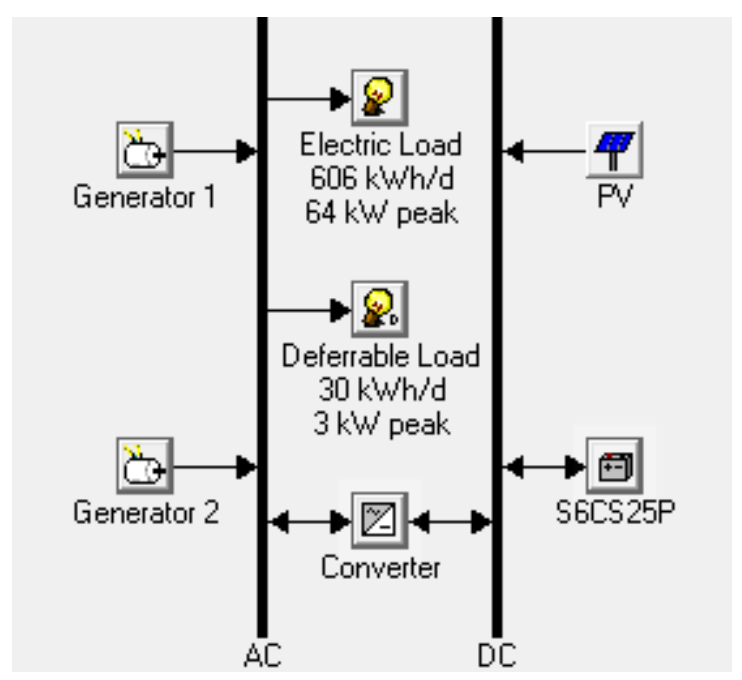

Fig. 6. Designed hybrid system in HOMER software

Rolls Surrette S6CS25P battery is selected in this research which is produced by North American manufacturer, Rolls Surrette (Asrari et al., 2012). Technical parameters and costs of the battery are summarized in Table 2.
Table 1. Technical parameters and costs of PV

\begin{tabular}{ll}
\hline Parameters/Costs & Value \\
\hline De-rating factor & $90 \%$ \\
Nominal operating cell temperature & $47^{\circ} \mathrm{C}$ \\
Temperature coefficient & $-0.5 \% /{ }^{\circ} \mathrm{C}$ \\
Efficiency at standard test condition & $13 \%$ \\
Ground reflectance & $20 \%$ \\
Capital cost & $\$ 5000 / \mathrm{kW}$ \\
Replacement cost & $\$ 2500 / \mathrm{kW}$ \\
Operating and maintenance cost & $\$ 1 / \mathrm{kW} /$ year \\
Lifetime & 25 years \\
Tracking system & No tracking \\
\hline
\end{tabular}

Table 2. Technical parameters and costs of the battery

\begin{tabular}{ll}
\hline Parameters/Costs & Value \\
\hline Nominal voltage & $6 \mathrm{~V}$ \\
Nominal capacity & $1500 \mathrm{Ah}(3 \mathrm{kWh})$ \\
Cost of capital & $\$ 1100$ \\
Cost of replacement & $\$ 1000$ \\
Cost of operating and maintenance & $\$ 10 /$ year \\
Minimum lifetime & 4 years \\
\hline
\end{tabular}

Table 3. Technical parameters and costs of the converter

\begin{tabular}{ll}
\hline Parameters/Costs & Value \\
\hline Efficiency & $90 \%$ \\
Cost of capital & $\$ 550 / \mathrm{kW}$ \\
Cost of replacement & $\$ 450 / \mathrm{kW}$ \\
Cost of operating and maintenance & $\$ 5 / \mathrm{kW} /$ year \\
Lifetime & 15 years \\
\hline
\end{tabular}

The battery is able to store a particular amount of DC electricity at constant round-trip energy efficiency and capable of limiting the time for charging or discharging without causing any damage.

\section{Converter}

A converter is required to preserve passing of energy between alternating and direct power system components. The output AC power of the inverter should 
be similar to or higher than the maximum load. Technical parameters and costs of the converter are summarized in Table 3 (Srivastava and Giri, 2016).

\section{Diesel Generator}

As mentioned above, currently, the electrical power supply in the village is achieved by utilizing 2 diesel generators of 50 and $25 \mathrm{~kW}$. Therefore, these generators are included in the simulation to compare the system with the other feasible systems.

The costs of capital and replacement of the generator are considered to be $\$ 500 / \mathrm{kW}$ and $\$ 400 / \mathrm{kW}$ respectively. Operating and maintenance cost is considered to be quite high, with $\$ 0.02 /$ hour $/ \mathrm{kW}$, this is because the village is located in a remote region, so, difficulty arises in transportation problem when maintenance is needed.

Diesel price is used for sensitivity analysis and 5 discrete values $(0.65,0.7,0.8,0.9,1 \$ / \mathrm{L})$ are introduced. Currently, the diesel price in Iraq is $\$ 0.65$ per liter (Global Petrol Prices, 2016).

\section{Cost Optimization}

First of all, the technical feasibility of the system ability in supplying the load demand is accessed by HOMER. Then, it determines the total cost of the project (net present cost). Net present cost which includes capital cost, replacement costs, operation and maintenance costs, fuel costs and salvage cost is calculated using (Dalton et al., 2009):

$$
N P C=\frac{C_{t o t}}{C R F(i, n)}
$$

where, $C_{t o t}$ is the total cost per year (\$/year), $i$ is the real interest rate $(\%)$ per year and $n$ is the lifetime of the project. The Capital Recovery Factor (CRF) is calculated using (Dalton et al., 2009):

$$
C R F(i, n)=\frac{i \times(1+i)^{n}}{(1+i)^{n}-1}
$$

The amount of Net Present Cost is determined by taking into account the Salvage Costs (SC) which are occur at the end of the lifetime of the project lifetime and is written as (Dalton et al., 2009):

$$
S C=C_{R C} \times \frac{T_{r e m}}{T_{c o m}}
$$

Here $C_{R C}$ is the cost of replacement (\$), $T_{r e m}$ is the remaining life (year) and $T_{\text {com }}$ is the lifetime (year) of the component.

The levelized Cost of Energy (COE) yields (Beccali et al., 2008):

$$
C O E=\frac{C_{t o t}}{E_{t o t}}
$$

where, $E_{\text {tot }}$ is the annual consumption of the total electricity ( $\mathrm{kWh} /$ year).

\section{Simulations and Results}

\section{Optimization Results}

Simulation was done based on 25 year's projection duration. Hundreds or thousands of hourly simulations are implemented in HOMER to guarantee preferable potential connection between the supply and the load demand and displays a listing of feasible systems which are ranked based on the total cost of the project. This strategy is considered in this simulation to guarantee that the total power supplied to the load is sufficient.

The simulation and optimization results show that the cheapest system is the standalone diesel generators, with the total Net Present Cost (NPC) of \$ 886434 for diesel price of $\$ 0.65 / \mathrm{L}$. The fuel consumption for this system is 87224 liter of diesel. This is not affirmative as the main goal is to minimize the using of diesel. The proposed hybrid PV/diesel system (60 kW PV, 50 and 25 $\mathrm{kW}$ generators and $40 \mathrm{~kW}$ converter) has a total NPC of \$ 921899 which is only 4\% more expensive than standalone diesel generator. Moreover, the fuel consumption is reducing to 56420 Liter of diesel. PV/ battery is the most expensive system. This is because of the high capital cost of PV, which is the main reason for high total NPC. The comparison of all feasible systems is listed in Fig. 7.

However, the price of renewable energy components is expected to fall whilst the price of diesel is increasing over time. As shown in Fig. 8, when the diesel price is as high as $\$ 1$ per liter, photovoltaic/diesel hybrid energy system with and without batteries has benefited significantly. In this case, the utilize of hybrid PV/diesel without battery $(60 \mathrm{~kW} \mathrm{PV}, 50$ and $25 \mathrm{~kW}$ generators and $40 \mathrm{~kW}$ converter) is found to have the least total NPC, \$ 1174331 with fuel consumption of $56420 \mathrm{~L}$, while PV/diesel/battery (60 kW PV, 50 and $25 \mathrm{~kW}$ generators, 100 strings batteries and $40 \mathrm{~kW}$ converter) has a total NPC of \$ 1240580 with fuel consumption of $41766 \mathrm{~L}$. If the off-grid diesel system is used to feed the load, the total NPC becomes about \$ 1276688 which is $8 \%$ higher than NPC of hybrid PV/diesel system without battery.

\section{Grid Extension}

In this part of results, a comparison between the cost of the off-grid hybrid energy system with the expansion of the grid has been presented. In Homer software, proper grid extension inputs are shown in Table 4. 


\begin{tabular}{|c|c|c|c|c|c|c|c|c|c|c|c|c|c|c|c|}
\hline Diesel Price $(\$ / L)$ & 0.65 & 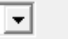 & & & & & & & & & & & & & \\
\hline Double click on a s & ystem b & elow for s & simulatic & on results. & & & & & & & & & & 60 & Categorized \\
\hline 雨的回回 & $\begin{array}{c}\mathrm{PV} \\
(\mathrm{kW})\end{array}$ & $\begin{array}{l}\text { Gen1 } \\
(\mathrm{kW})\end{array}$ & $\begin{array}{l}\text { Gen2 } \\
(\mathrm{kW})\end{array}$ & S6CS25P & \begin{tabular}{|l|}
$\begin{array}{l}\text { Conv. } \\
(\mathrm{kW})\end{array}$ \\
\end{tabular} & $\begin{array}{l}\text { Initial } \\
\text { Capital }\end{array}$ & $\begin{array}{l}\text { Operating } \\
\text { Cost (\$/yr) }\end{array}$ & $\begin{array}{l}\text { Total } \\
\text { NPC }\end{array}$ & $\mid \begin{array}{c}\mathrm{COE} \\
(\mathrm{S} / \mathrm{kWh})\end{array}$ & \begin{tabular}{|l} 
Ren. \\
Frac.
\end{tabular} & $\begin{array}{l}\text { Capacity } \\
\text { Shortage }\end{array}$ & $\begin{array}{c}\text { Diesel } \\
\text { (L) }\end{array}$ & $\begin{array}{l}\text { Gen1 } \\
\text { (hrs) }\end{array}$ & $\begin{array}{c}\text { Gen2 } \\
\text { (hrs) }\end{array}$ & $\begin{array}{c}\text { Batt. If. } \\
\text { (yr) }\end{array}$ \\
\hline$\theta 0$ & & 25 & 50 & & & $\$ 37.500$ & 66.409 & $\$ 886,434$ & 0.299 & 0.00 & 0.00 & 87.224 & 4,188 & 5,208 & \\
\hline 90 & 60 & 25 & 50 & & 40 & $\$ 359.500$ & 43,995 & $\$ 921.899$ & 0.311 & 0.45 & 0.00 & 56.420 & 6.125 & 2.125 & \\
\hline 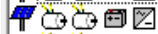 & 60 & 25 & 50 & 100 & 40 & $\$ 469,500$ & 44,571 & $\$ 1,039,261$ & 0.350 & 0.48 & 0.00 & 50,650 & 5,615 & 1,833 & 12.0 \\
\hline 可田 & & 25 & 50 & 100 & 10 & $\$ 153,000$ & 71,635 & $\$ 1,068,742$ & 0.360 & 0.00 & 0.00 & 87,103 & 4,194 & 5,196 & 12.0 \\
\hline$\square$ & 80 & & 50 & & 40 & $\$ 447,000$ & 53,643 & $\$ 1,132,741$ & 0.383 & 0.51 & 0.01 & 66,186 & & 7.117 & \\
\hline 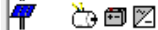 & 60 & & 50 & 100 & 40 & $\$ 457,000$ & 53,880 & \$ $1,145,764$ & 0.387 & 0.48 & 0.00 & 59,611 & & 6.711 & 12.0 \\
\hline 圈 & 170 & 25 & & 160 & 40 & $\$ 1,060,500$ & 20,642 & \$1.324.377 & 0.450 & 0.90 & 0.01 & 14,956 & 2,996 & & 12.0 \\
\hline 图 & 195 & & & 420 & 70 & $\$ 1,475,500$ & 23,007 & $\$ 1,769,608$ & 0.602 & 1.00 & 0.01 & & & & 12.0 \\
\hline
\end{tabular}

Fig. 7. The overall optimization results (Diesel price $\$ 0.65 / \mathrm{L}$ )

\begin{tabular}{|c|c|c|c|c|c|c|c|c|c|c|c|c|c|c|c|}
\hline \multicolumn{2}{|l|}{ Diesel Price $(\$ / L) 1$} & \multicolumn{14}{|l|}{-} \\
\hline \multicolumn{14}{|c|}{ Double click on a system below for simulation results. } & \multicolumn{2}{|c|}{ - Categorized } \\
\hline 3 & $\begin{array}{c}\begin{array}{c}P V \\
(\mathrm{~kW})\end{array} \\
\end{array}$ & $\begin{array}{l}\text { Gen1 } \\
(\mathrm{kW})\end{array}$ & $\begin{array}{l}\text { Gen2 } \\
(\mathrm{kW})\end{array}$ & S6CS25P & $\begin{array}{l}\text { Conv. } \\
(\mathrm{kW})\end{array}$ & $\begin{array}{l}\text { Initial } \\
\text { Capital }\end{array}$ & $\begin{array}{l}\text { Operating } \\
\text { Cost (\$/yr) }\end{array}$ & $\begin{array}{l}\text { Total } \\
\text { NPC }\end{array}$ & $\left|\begin{array}{c}\mathrm{COE} \\
(\mathrm{s} / \mathrm{kWh})\end{array}\right|$ & $\begin{array}{l}\text { Ren. } \\
\text { Frac. }\end{array}$ & \begin{tabular}{|l|} 
Capacity \\
Shortage
\end{tabular} & $\begin{array}{c}\text { Diesel } \\
(\mathrm{L})\end{array}$ & $\begin{array}{l}\text { Gen1 } \\
\text { (hrs) }\end{array}$ & $\begin{array}{c}\text { Gen2 } \\
\text { (hrs) }\end{array}$ & \begin{tabular}{|c|}
$\begin{array}{c}\text { Batt. Lf. } \\
(\mathrm{yr})\end{array}$ \\
\end{tabular} \\
\hline$\theta \emptyset$ & 60 & 25 & 50 & & 40 & $\$ 359,500$ & 63,742 & $\$ 1,174,331$ & 0.396 & 0.45 & 0.00 & 56.420 & 6.125 & 2,125 & \\
\hline (๑) & 80 & 25 & 50 & 100 & 40 & $\$ 569.500$ & 52,496 & $\$ 1,240,580$ & 0.418 & 0.60 & 0.00 & 41,766 & 5.474 & 1,216 & 12.0 \\
\hline$\theta 0$ & & 25 & 50 & & & $\$ 37,500$ & 96.938 & $\$ 1,276,688$ & 0.430 & 0.00 & 0.00 & 87,224 & 4,188 & 5.208 & \\
\hline 目 & 160 & 25 & & 220 & 60 & $\$ 1,087,500$ & 21.409 & $\$ 1,361,176$ & 0.462 & 0.94 & 0.01 & 8.168 & 1.496 & & 12.0 \\
\hline 車图 & 80 & & 50 & 100 & 60 & $\$ 568,000$ & 63.512 & $\$ 1,379,896$ & 0.465 & 0.60 & 0.00 & 49,523 & & 5,709 & 12.0 \\
\hline 目 & 80 & & 50 & & 40 & $\$ 447,000$ & 76,808 & $\$ 1,428,870$ & 0.483 & 0.51 & 0.01 & 66.186 & & 7.117 & \\
\hline 000 & & 25 & 50 & 100 & 10 & $\$ 153,000$ & 102,122 & $\$ 1,458,456$ & 0.492 & 0.00 & 0.00 & 87.103 & 4,194 & 5,196 & 12.0 \\
\hline 图 & 195 & & & 420 & 70 & $\$ 1,475,500$ & 23,007 & $\$ 1,769,608$ & 0.602 & 1.00 & 0.01 & & & & 12.0 \\
\hline
\end{tabular}

Fig. 8. The overall optimization results (Diesel price \$1/L)

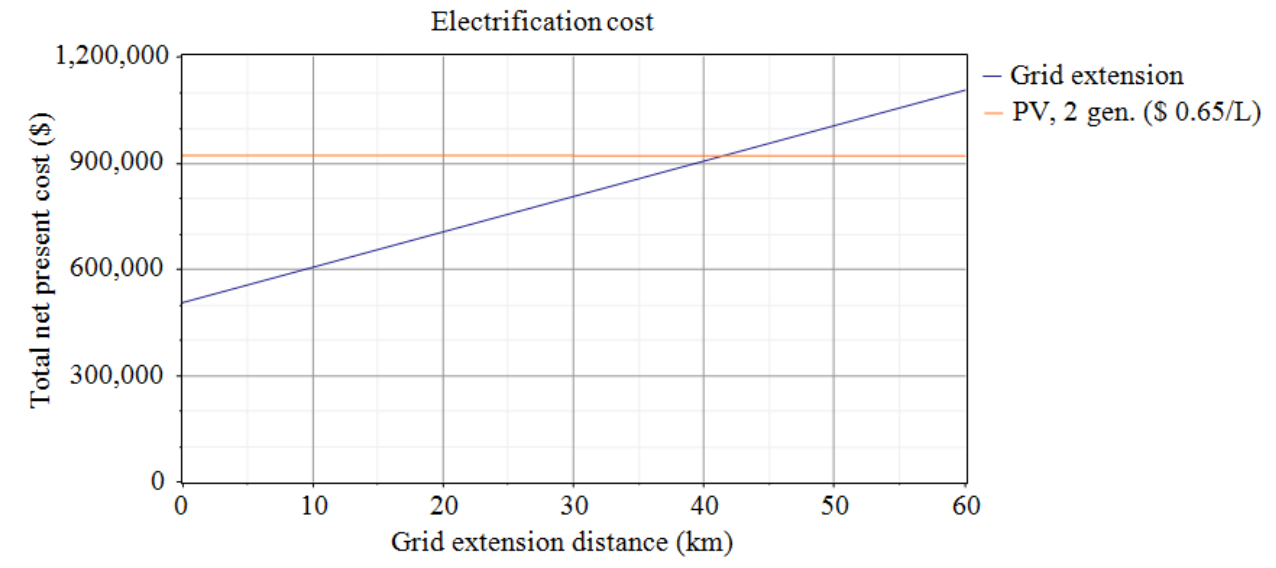

Fig. 9. Breakeven grid extension distance (Diesel price \$ 0.65/L)

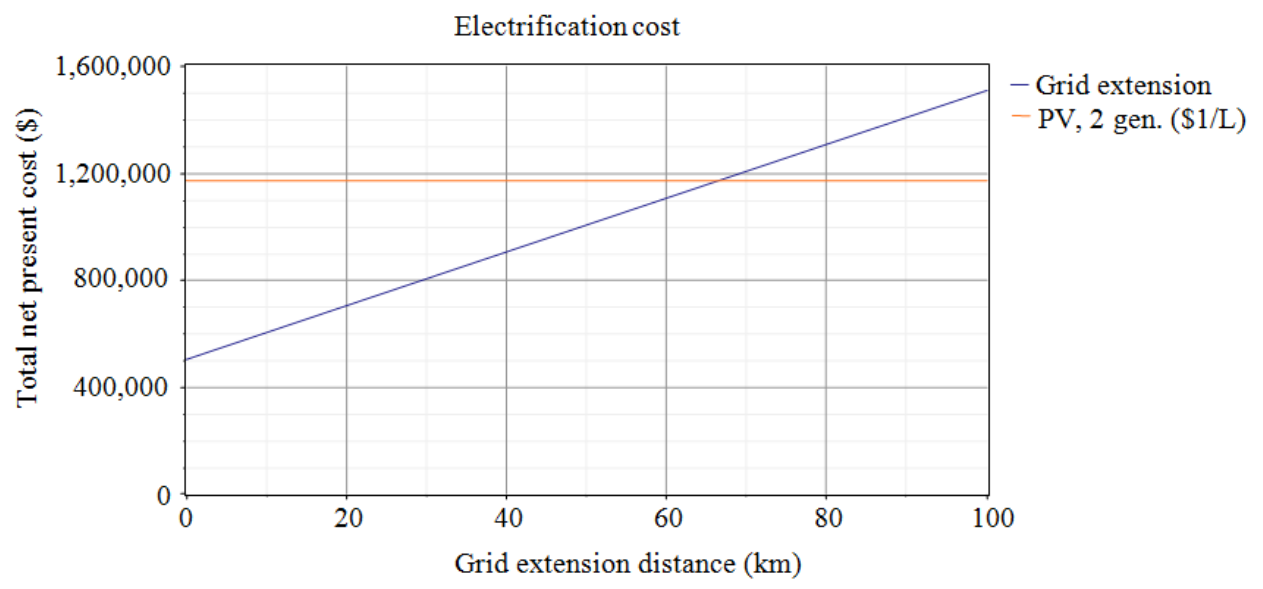

Fig. 10. Breakeven grid extension distance (Diesel price \$1/L) 
Table 4. Proper grid extension inputs

\begin{tabular}{ll}
\hline Parameters/Costs & Value \\
\hline Cost of capital & $8000 \$ / \mathrm{km}$ \\
Cost of operating and maintenance & $160 \$ / \mathrm{yr} / \mathrm{km}$ \\
Grid power price & $0.17 \$ / \mathrm{kWh}$. \\
\hline
\end{tabular}

Table 5. Concentrations of pollutants for all feasible systems that include diesel generators

\begin{tabular}{|c|c|c|c|c|c|c|c|}
\hline Variable & $\begin{array}{l}\text { Case 1: Two } \\
\text { diesel } \\
\text { generators } \\
50 \& 25 \mathrm{~kW} \\
\end{array}$ & $\begin{array}{l}\text { Case 2: Two } \\
\text { diesel } \\
\text { generators } \\
50 \& 25 \mathrm{~kW} \\
\text { with PV }\end{array}$ & $\begin{array}{l}\text { Case 3: Two } \\
\text { diesel } \\
\text { generators } \\
50 \& 25 \mathrm{~kW} \\
\text { with PV } \\
\text { and battery }\end{array}$ & $\begin{array}{l}\text { Case 4: Two } \\
\text { diesel } \\
\text { generators } \\
50 \& 25 \mathrm{~kW} \\
\text { with battery }\end{array}$ & $\begin{array}{l}\text { Case 5: One } \\
\text { diesel } \\
\text { generator } \\
50 \mathrm{~kW} \\
\text { with PV }\end{array}$ & $\begin{array}{l}\text { Case 6: One } \\
\text { diesel } \\
\text { generator } \\
50 \mathrm{~kW} \\
\text { with PV } \\
\text { and battery }\end{array}$ & $\begin{array}{l}\text { Case 7: One } \\
\text { diesel } \\
\text { generator } \\
25 \mathrm{~kW} \\
\text { with PV } \\
\text { and battery }\end{array}$ \\
\hline \multicolumn{8}{|l|}{ Pollutant Emission (kg/year) } \\
\hline Carbon dioxide $\left(\mathrm{CO}_{2}\right)$ & 229688 & 148572 & 133378 & 229371 & 174290 & 156974 & 39385 \\
\hline Carbon monoxide (CO) & 567 & 367 & 329 & 566 & 430 & 387 & 97.2 \\
\hline Unburned hydrocarbons (UHC) & 62.8 & 40.6 & 36.5 & 62.7 & 47.7 & 42.9 & 10.8 \\
\hline Particulate matter (PM) & 42.7 & 27.6 & 24.8 & 42.7 & 32.4 & 29.2 & 7.33 \\
\hline Sulfur dioxide $\left(\mathrm{SO}_{2}\right)$ & 461 & 298 & 268 & 461 & 350 & 315 & 79.1 \\
\hline Nitrogen oxides (NOx) & 5059 & 3272 & 2938 & 5052 & 3839 & 3457 & 867 \\
\hline
\end{tabular}

Figure 9 shows that the grid extension case is more expensive than hybrid system (60 kW PV, 50 and $25 \mathrm{~kW}$ generators and $40 \mathrm{~kW}$ converter) if the distance between the system and the grid is more than $41.6 \mathrm{~km}$. This distance is called breakeven grid extension distance. It takes place in the case that NPC of both grid extension stand-alone system is the same. The distance between the village and the nearest grid is about $70 \mathrm{~km}$. Therefore, for a diesel price of $\$ 0.65 / \mathrm{L}$, the off-grid system is less expensive and hence more feasible than a grid expansion for this village. The simulation result is repeating with diesel price of $\$ 1 / \mathrm{L}$. It is found that the standalone system is still cheaper than the grid extension with breakeven grid extension distance of $66.7 \mathrm{~km}$ as shown in Fig. 10.

\section{Environmental Benefits}

Recently, the world comes to an agreement that something needs to be done about global warming and climate change so as to reduce the pollution of gas emission. In HOMER software, the emissions factors, which are measured in units of grams of pollutant emitted per liter of fuel consumed, are used to calculate the amount of the emissions of the air pollutants. The integration of PV and diesel generator capable of reducing the pollution of gas emission as compared to the standalone diesel system. The simulation results present that the using of two diesel generators results in a total of $229688 \mathrm{~kg} / \mathrm{yr}$ of carbon dioxide released to the atmosphere of the village. The proposed hybrid energy system (7) significantly minimizes the total emissions of the system as compared to whole others cases. It reduces the $\mathrm{CO}_{2}$ emission to $39385 \mathrm{~kg} / \mathrm{yr}$. Although case- 2 and case-3 emit more than Case-7, however, when compared to the standalone diesel, they are still quite environmentally friendly. The concentrations of other pollutants for all the feasible systems that include diesel generators are summarized in Table 5.

\section{SWOT Analysis of PV/Battery/Diesel Hybrid Energy System in Iraq}

SWOT is an acronym for strengths, weaknesses, opportunities and threats. Strengths and weaknesses are considered to be internal factors that can be easily controlled. While, opportunities and threats are considered to be external factors in which a little control can be done over them. SWOT Analysis is the most familiar method for audit and analysis of the outright strategic status of the business and its environment. Its main objective is to select the strategies that will produce a stationary specified business model which will recognize the resources and abilities of the organization to be suitable for the environment needed in which the firm works (Abdul Khader and Idris, 2016). The outcomes of the analysis for the economic, environmental, technical, community/social aspects are presented in this section.

\section{Strengths}

- Iraq is blessed with more than 340 sunlit days per year. As long as we have the sun, solar energy will be available

- Solar panels can be placed anywhere. It is possible to install them in houses and commercial roof tops

- Reduction of the dependence on the fossil fuels

- Reduction of environmental impact

- Reduction of noise level of diesel generators

- Low and predictable O\&M costs

\section{Weaknesses}

- The cost of installation of PV is expensive

- Lack of technical support for the rural areas

- Requirement of greater support through a national policy

- Power system stability problem in the case of high penetration of renewable energy 


\section{Opportunities}

- New job opportunities

- Rising number of companies interested in the energy sector may results in reduction in cost of solar cells

- The environment issue makes the people worry from the installing of conventional power plants in their areas and this will force the government to basically rely on solar energy

\section{Threats}

- It is improbable that the conventional energy production sector will be diminished in the near future and this will prevent the people from alteration

- No available market study in Iraq

- Limited practical experiences

- Incompetent legal framework (Standards, regulations and permissions of installation)

\section{Conclusion}

From the simulation of HOMER software, it has been found that the use of photovoltaic/diesel hybrid energy system can significantly minimize the reliance on the depleting energy resource. Although it is more expensive than standalone diesel generators, it is capable of reducing the emissions, such as $\mathrm{CO}_{2}$, this reduces the global warming. It is also proven that if the price of diesel increases significantly, the use of $\mathrm{PV} /$ diesel system will be more economical. With a projected lifetime of 25 years, $6 \%$ annual real interest rate and diesel price of $\$ 1 /$ liter, it is found that the use of photovoltaic together with the two diesel generator system can attain significantly lower NPC than the offgrid diesel system. Furthermore, for the selected village, stand-alone $\mathrm{PV} /$ diesel generators power system is more feasible than grid extension. As a conclusion, the hybrid $\mathrm{PV} /$ diesel system is a suitable choice in remote areas, especially in exchanging or upgrading current standalone diesel systems in Iraq.

\section{Acknowledgement}

Authors are grateful to the anonymous reviewers and the editor for detailed comments. The usual disclaimer applies.

\section{Funding Information}

There is no funding to be mentioned.

\section{Author's Contributions}

The authors participated evenly in writing this manuscript.

\section{Ethics}

This research is authentic and consists of unpublished material. All the authors have read and approved this paper.

\section{References}

Abdul Khader, J. and M. Idris, 2016. SWOT Analysis of solar energy in India. Int. J. Commerce, Bus. Manage., 5: 323-326.

Al-Douri, Y. and F.M. Abed, 2015. Solar energy status in Iraq: Abundant or not-Steps forward. J. Renewable Sustainable Energy, 8: 025905-025905. DOI: $10.1063 / 1.4947076$

Al-Karaghouli, A. and L.L. Kazmerski, 2010. Optimization and life-cycle cost of health clinic PV system for a rural area in southern Iraq using HOMER software. Solar Energy, 84: 710-714.

DOI: 10.1016/J.SOLENER.2010.01.024

Asrari, A., A. Ghasemi and M.H. Javidi, 2012. Economic evaluation of hybrid renewable energy systems for rural electrification in Iran-A case study. Renewable Sustainable Energy Rev., 16: 3123-3130. DOI: 10.1016/j.rser.2012.02.052

Beccali, M., S. Brunone, M. Cellura and V. Franzitta, 2008. Energy, economic and environmental analysis on RET-hydrogen systems in residential buildings. Renewable Energy, 33: 366-382. DOI: $10.1016 /$ j.renene.2007.03.013

Dalton, G.J., D.A. Lockington and T. Baldock, 2009. Feasibility analysis of stand-alone renewable energy supply options for a large hotel. Renewable Energy, 33: 1475-1490. DOI: 10.1016/j.renene.2007.09.014

Global Petrol Prices, 2016.

Kaldellis, J.K., 2010. Optimum hybrid photovoltaicbased solution for remote telecommunication stations. Renewable Energy, 35: 2307-2315. DOI: $10.1016 /$ j.renene.2010.03.029

Kazem, A.A., M.T. Chaichan and H.A. Kazem, 2014. Dust effect on photovoltaic utilization in Iraq: Review article. Renewable Sustainable Energy Rev., 37: 734-749. DOI: 10.1016/j.rser.2014.05.073

Nandi, S.K. and H.R. Ghosh, 2009. A wind-PV-battery hybrid power system at Sitakunda in Bangladesh. Energy Policy, 37: 3659-3664. DOI: 10.1016/j.enpol.2009.04.039

Nawawi, Z., A.S. Aziz, Z. Buntat, M.A.B. Sidik and H.J. Kareem et al., 2016. Performance Analysis of a VPV/FC hybrid system for generating electricity in Iraq's remote areas. Telkomnika, 14: 411-422. DOI: 10.12928/telkomnika.v14i2.3749

Nour, M. and G. Rohani, 2014. Prospect of stand-alone PV-diesel hybrid power system for rural electrification in UAE. Int. J. Renewable Energy Res., 4: 749-758. 
Shafiullah, G., A.M.T. Oo, S. Ali, D. Jarvis and P. Wolfs, 2010. Economic analysis of hybrid renewable model for subtropical climate. Int. J. Thermal Environm. Eng., 1: 57-65. DOI: 10.5383/ijtee.01.02.001

Srivastava, R. and V.K. Giri, 2016. Optimization of hybrid renewable resources using HOMER. Int. J. Renewable Energy Res., 6: 157-163.
Sunderland, K., T. Woolmington, J. Blackledge and M. Conlon, 2013. Small wind turbines in turbulent (urban) environments: A consideration of normal and Weibull distributions for power prediction. J. Wind Eng. Industrial Aerodynam., 121: 70-81. DOI: $10.1016 /$ j.jweia.2013.08.001 